\title{
ENTOMOLOGY
}

\section{New record of Ellipsocoris kalashiani Carapezza 2009 in Europe, found in Apulia, Italy (Heteroptera: Scutelleridae)}

\author{
I. Laterza, ${ }^{1}$ P. Dioli ${ }^{2}$ \\ ${ }^{1}$ Department of Soil, Plant and Food Sciences (DiSSPA), University of Bari Aldo Moro, Bari, Italy; ${ }^{2}$ Department of \\ Entomology, Natural History Museum, Milano, Italy
}

\begin{abstract}
Ellipsocoris kalashiani is recorded for the first time in Apulia (Southern Italy). The specie was described by Carapezza (2009) from Eastern Turkey and Western Armenia, but no records have ever been reported for Europe. Recently, few individuals of this species were found in Alta Murgia National Park (Apulia, Italy), a Special Protection Area (SPA) and Site of Community Importance (SCI), characterized by natural forests and dry grassland habitats, with Mediterranean-steppe vegetation. The specimens were collected in two different localities, about $40 \mathrm{~km}$ apart from each other, suggesting a long-standing presence in that area. This study
\end{abstract}

Correspondence: : Ilaria Laterza, Department of Soil, Plant and Food Sciences (DiSSPA), University of Bari Aldo Moro, Via G. Amendola 165/a, 70126 Bari, Italy.

E-mail: ilaria.laterza@uniba.it

Key words: Heteropteran fauna, Mediterranean steppe, dry grassland habitat, taxonomy, Alta Murgia National Park.

Acknowledgments: The authors are grateful to Prof. E. de Lillo (University of Bari Aldo Moro) and Prof. A. Carapezza (Palermo) for useful suggestions and accurate revision; the Alta Murgia National Park authorities which allowed them to investigate the Pentatomoidea fauna in the Park's area; Rosa Colucci for her precious help in sampling.

Contributions: The authors contributed equally.

Conflict of interest: The authors declare no potential conflict of interest.

Funding: None.

Received for publication: 25 November 2020.

Revision received: 28 December 2020.

Accepted for publication: 8 Janaury 2021.

${ }^{\circ}$ Copyright: the Author(s), 2020

Licensee PAGEPress, Italy

Journal of Entomological and Acarological Research 2020; 52:9529 doi:10.4081/jear.2020.9529

This article is distributed under the terms of the Creative Commons Attribution Noncommercial License (by-nc 4.0) which permits any noncommercial use, distribution, and reproduction in any medium provided the original author(s) and source are credited. provides the first report of the species for the Italian Heteroptera fauna and several hypotheses about its presence there. However, further investigations are needed in order to clarify some ecological aspects, such as its unknown host plant.

\section{Introduction}

The family Scutelleridae contains approximately 100 genera and at least 531 species, distributed worldwide (Schuh \& Weirauch, 2020), with eight genera reported for Italian Heteroptera fauna (Faraci \& Rizzotti-Vlach, 1995). The members of this family are known as "shield bugs" due to their enlarged scutellum covering almost the entire abdomen. Scutelleridae are mostly generalist polyphagous and they are not considered as crop pest, excepting for some species belonging to the Eurygaster genus that have been reported as pest on wheat and grasses, and for several species that might locally became pest, feeding on developing seeds (Javahery et al., 2000). The genus Ellipsocoris Mayr, 1864 contains four species: E. kalashiani Carapezza, 2009, from Armenia and Eastern Turkey; E. pericarti Carapezza, 2009, from Azerbaijan; E. tamerlani Kiritshenko, 1914 from Afghanistan, Iran, Tadzhikistan and Uzbekistan; E. trilineatus Mayr, 1864, from Armenia, Asian Turkey, Egypt, Iran, Israel, Lebanon and Syria. The distribution of the genus is generally referred to the Central-Asian and Middle-East; no records have been reported from the Italian peninsula and Europe and limited information is available on their ecology. Few studies investigated the Heteroptera composition of the Apulia region (Southern Italy), pointing out the need for further investigations in an area which has an interesting location in the Mediterranean basin. In particular, the "Alta Murgia" National Park (AMNP) is located in SE Italy, extending in Apulia and Basilicata regions, with a surface of $70,000 \mathrm{ha}$, at an altitude between $300 \mathrm{~m}$ and $700 \mathrm{~m}$ asl. The northwestern part, called "Alta Murgia", is a Special Protection Area (SPA) and Site of Community Importance (SCI) IT9120007. The area is characterized by a Mediterranean climate and a variety of habitats, mainly large areas of pastures and sown lands, with small "Eastern white oak woods" of Quercus pubescens Willd., pine forest mainly composed by Pinus halepensis Mill. and dry grassland, that can be described as "Eastern sub-Mediterranean dry grasslands (Scorzoneratalia villosae)" and "Pseudo-steppe with grasses and annuals of the Thero-Brachypodietea". The moderated human interference together with the climatic and geological properties of this land provides a highly conservative environment for biodi- 
versity, especially those areas typically described as "Mediterranean steppe grassland", "steppe grassland" or "steppe", referring to grasslands with perennial caespitose grasses and some rare plant species such as Carum multiflorum Boiss., Campanula versicolor Andrews, Scrophularia lucida L., Aurinia saxatilis (L.) Desv. and Asyneuma limonifolium (L.) Janch., in a Mediterranean bioclimate (Terzi \& Marvulli, 2006). The present paper reports the first evidence of E. kalashiani for Apulia region and the Italian Heteroptera fauna, providing also photographic images of collected specimens which may help other researchers in future identifications of the species.

\section{Materials and methods}

\section{Insect sampling and identification}

Insects were collected by the first author, using an entomological sweeping net, on a $100 \mathrm{~m}$ long transept, during a study aimed to investigate the Pentatomoidea fauna in twelve different location of AMNP. The identification of the genus Ellipsocoris was made using the Keys of Heteroptera of Europe and Mediterranean countries (Stichel, 1962) while the species was identified using the differential diagnosis made by Carapezza (2009) by the second author. The specimens are preserved in the Entomological Museum of the Department of Soil, Plant and Food Sciences (University of Bari, Bari) and in the private collection of P. Dioli (Sondrio) and of I. Laterza (Bari) as labelled dry specimens.

\section{Study areas}

The specimens were collected in "steppe" habitats in two locations: "Pulicchio di Gravina" (PG) and "Foresta Mercadante" (FM).

The PG (Figure 1A) area is characterized by conifers, mainly Aleppo pines (Pinus halepensis Mill.), and small "steppe" surrounded by cereals and pulse crops; the sampling area covers about $18,000 \mathrm{~m}^{2}$ surrounded by the conifer forest.

The FM area consists of a conifer forest of Aleppo pines surrounded by olive and legumes orchards, sometimes with small non-cultivated area referable to a "steppe" habitat (Figure 1B); the sampling site is around $5,200 \mathrm{~m}^{2}$ bordering an olive grove and cereal crops.

\section{Results}

\section{Material examined}

A total of five specimens were recorded (four females and one male).

ITALY - APULIA: Bari Province, Gravina di Puglia, Pulicchio di Gravina (4053'52.20”N, 16²5'10.44”E) 01.VII.2020, 1 ex., 28.VII.2020, 1 ex. leg. I. Laterza; ibidem, Cassano delle Murge, Foresta Mercadante (4052'22.53”N, 1643'9.33”E), 29.VI.2020, 3 ex. leg. I. Laterza.

According to Carapezza (2009), the collected specimens belong to E. kalashiani considering the following characters:

- absence of a Y-shaped pale area in the posterior part of scutellum (as in E. pericarti and E. tamerlani);

- the medial pale strip of the head is about twice wider than the same on pronotum and scutellum and sometimes little visible (Figure 2). In E. trilineatus the medial pale strip is not inter-
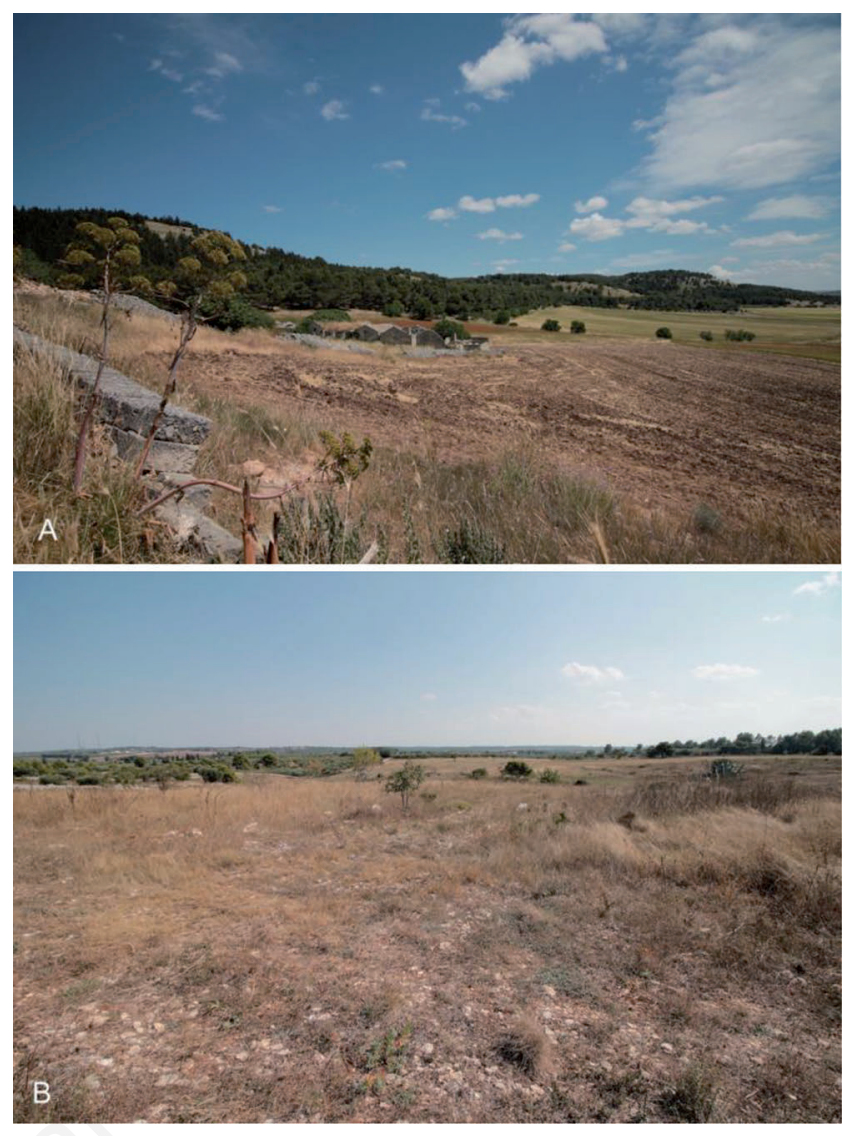

Figure 1. Sampling area: Pulicchio di Gravina (A), "steppe" habitat with Foresta Mercadante in the background (B).

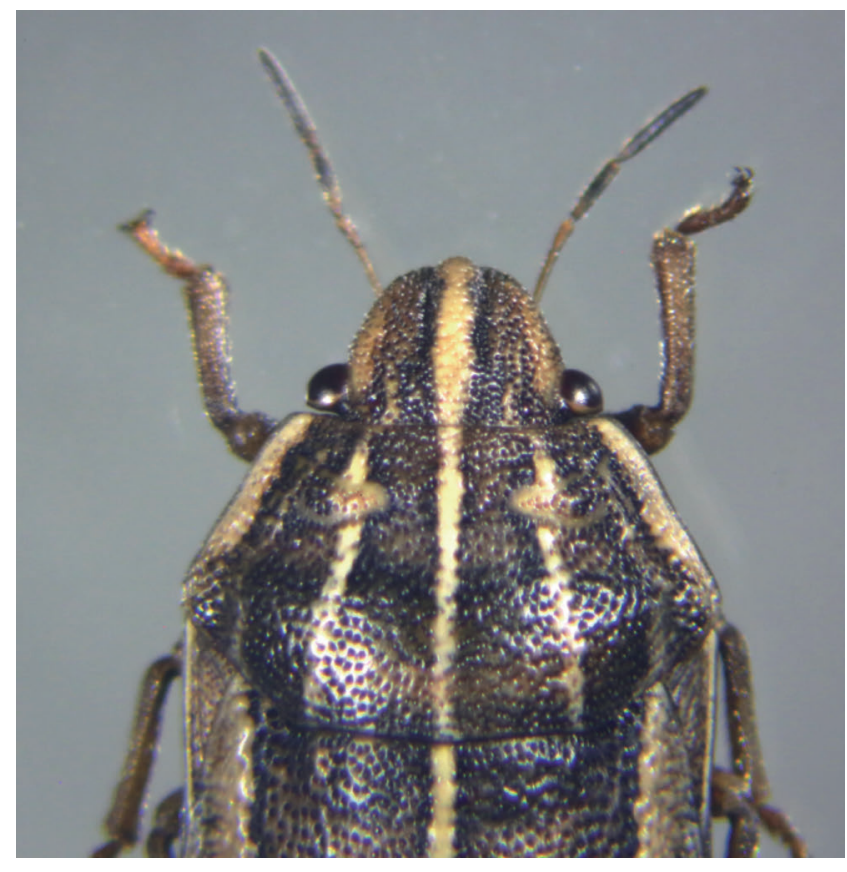

Figure 2. Details of the first antennal segment hidden under the head, and of medial pale stripe of heads. 
rupted and uniform in width from apex of clypeus to posterior margin of scutellum;

- the discal part of pronotum in E. kalashiani has three distinct pale stripes, while in E. trilineatus there is one only large medial stripe;

- the marginal band on pronotum is evident, but it doesn't reach the humeral angle, on the contrary it runs along the whole lateral margin in E. trilineatus;
- pale and dark areas of the head, pronotum and scutellum are little defined and feebly contrasted in some specimens (Figures 3-5);

- the median pale stripe from apex of clypeus to posterior margin of scutellum is sometimes interrupted (in E. trilineatus it is never interrupted);

- first antennal segment short and almost completely hidden under the head (Figure 2) (in E. trilineatus it is almost totally visible from above).
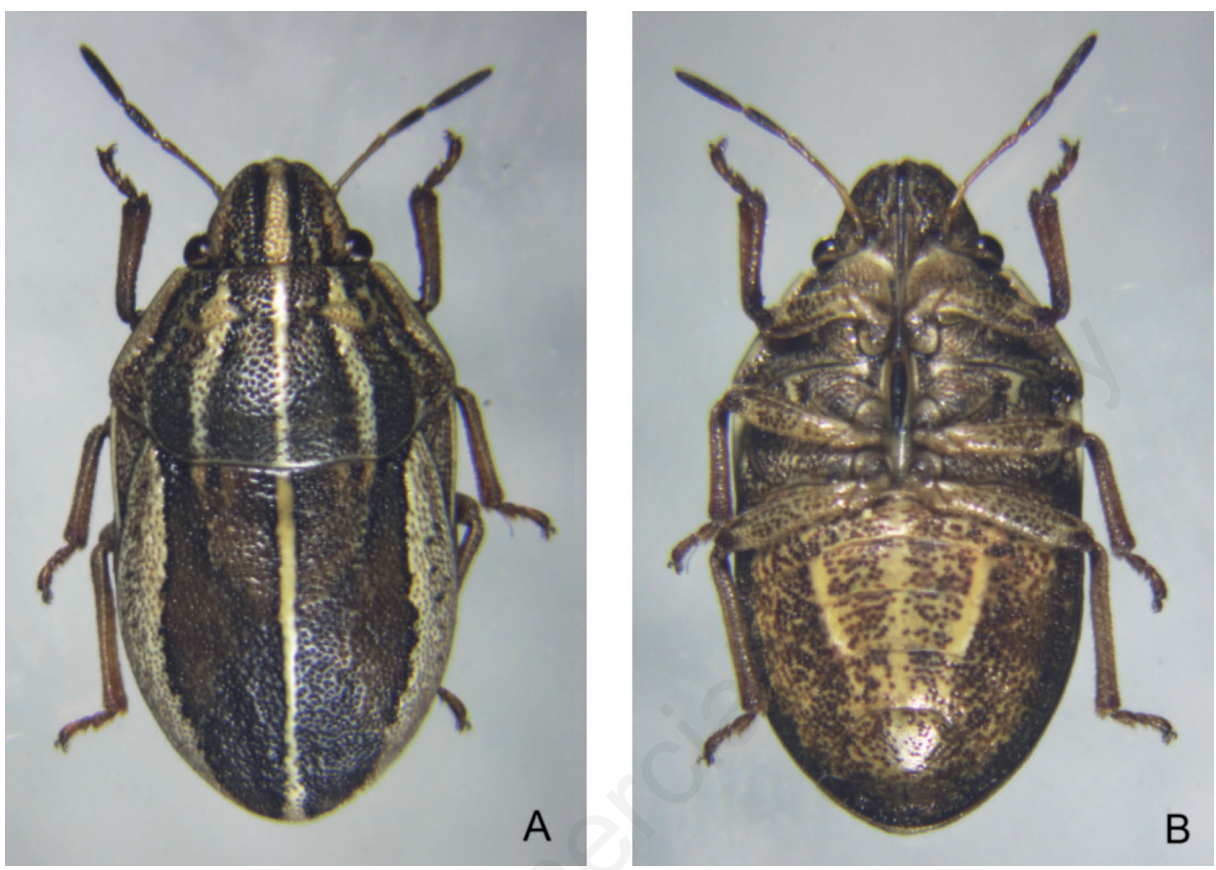

Figure 3. Dorsal (A) and ventral (B) view of a female.
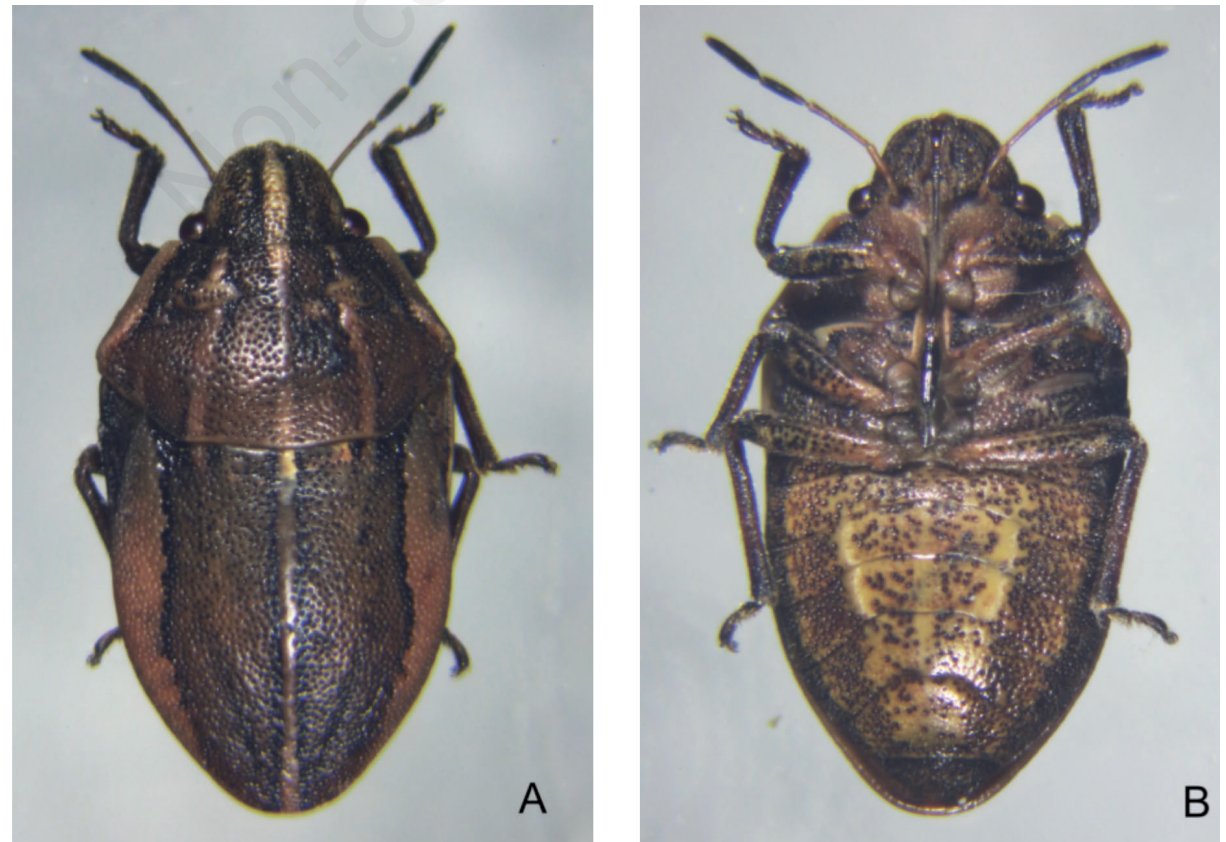

Figure 4. Dorsal (A) and ventral (B) view of a male. 


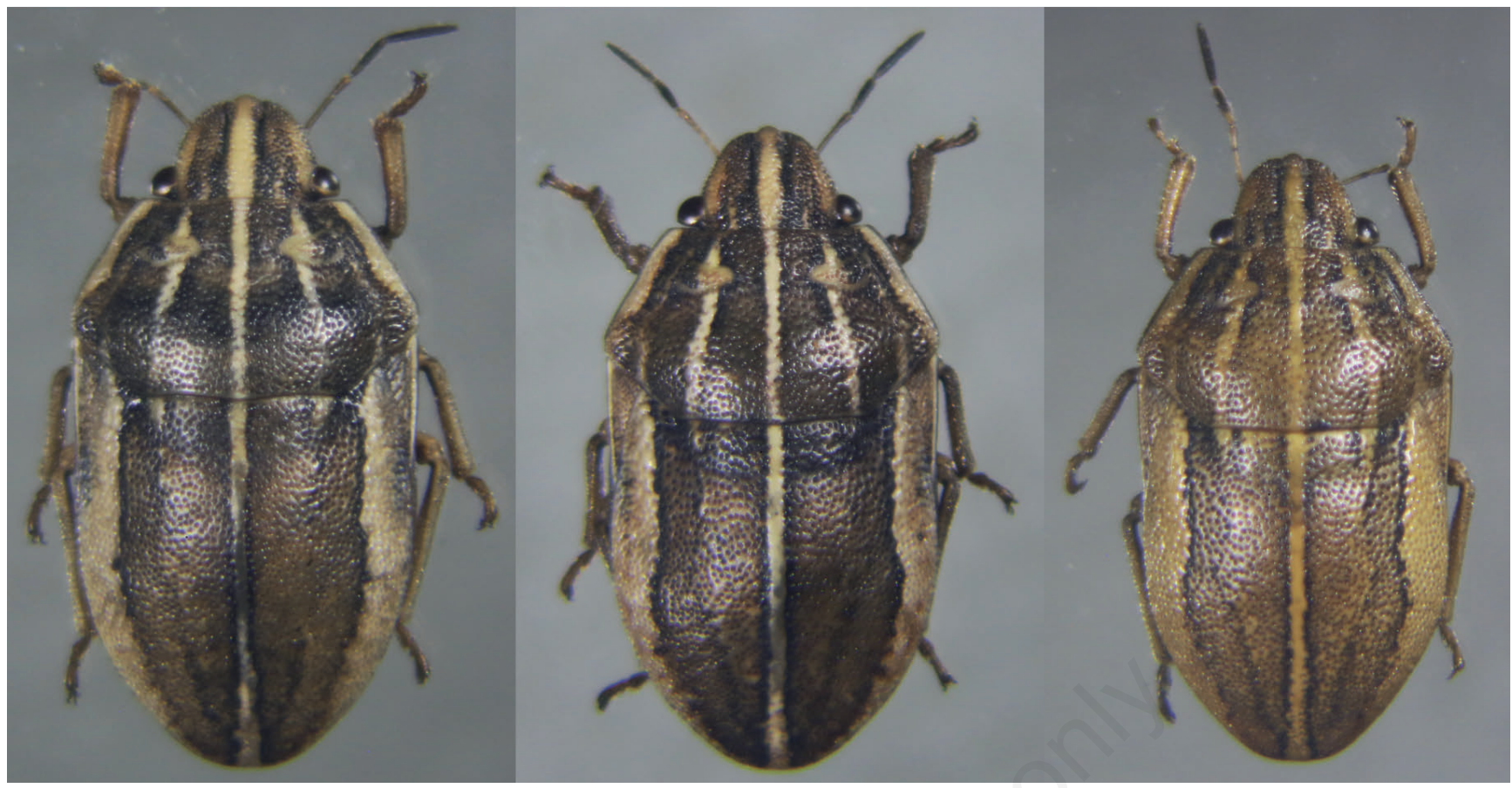

Figure 5. Color variation in three females of E. kalashiani.

\section{Discussion and conclusions}

Little information is available on E. kalashiani distribution and ecology. The detection of E. kalashiani in two different locations of AMNP, about $40 \mathrm{~km}$ away from each other, in an area with little human presence and far from the Adriatic Sea, suggests that it was not newly introduced and quite widespread in this territory. The introduction pathway is unknown, very likely, it is a steppe relict with a disjunct distribution whose survival depended on the special geomorphological and climatic conditions of the area where it was found, and on the absence or disappearance of suitable environments in intermediate regions. However, the possibility of finding it in suitable areas of Anatolia and the Balkan peninsula cannot be excluded, and further insight is needed to specify its current spread in other locations of AMNP and of Apulia region. Considering alternative hypotheses of introduction, it cannot also be excluded that it established in ancient historical times due to human activity or to commercial trade between local populations from the two areas, in fact eggs and nymphs of several Heteroptera species might be transported over long distance with host plants (Rabitsch, 2010). The material examined by Carapezza (2009) was collected in mountain steppe of Armenia, but no host plant was highlighted. Scrophulariaceae was mentioned as host plant for the genus Ellipsocoris but, considering the collecting method applied in the current study, it was not possible to observe directly individuals on plants. However, it is worthy of interest the presence of Scrophularia lucida L. in AMNP (Cotecchia, 2010), but further investigation is needed to clarify this aspect.

\section{References}

CARAPEZZA A., 2009 - On some Old World Scutelleridae (Heteroptera) - Nouv. Rev. Entomol. 25: 197-212.

COTECCHIA I.V., 2010 - Quadro conoscitivo ed interpretativo. Redazione del Piano per il Parco e del Regolamento del Parco nazionale dell'Alta Murgia

FARACI F., RIZZOTTI-VLACH M., 1995 - Heteroptera. In: MINELLI, A., RUFFO, S., LA POSTA, S. (Eds.), Checklist delle specie della fauna italiana, 41. Calderini Bologna: 1-56.

MAYR G.L., 1864 - Diagnosen neuer Hemipteren. - Verh. Zool.Bot. Ges. Wien 14: 903-914

RABITSCH W., 2010 - True Bugs (Hemiptera, Heteroptera) Chapter 9.1. In: ROQUES A. et al. (Eds). Alien terrestrial arthropods of Europe - BioRisk 4: 403-407.

JAVAHERY M., SCHAEFER C.W., LATTIN J.D., 2000 - Shield bugs (Scutelleridae). In: SCHAEFER C.W.,

SCHUH R.T., WEIRAUCH, C., 2020 - True Bugs of the World (Hemiptera: Heteroptera): Classification and Natural History Monography series.

STICHEL W., 1955-1962. - Illustrierte Bestimmungstabellen der Wanzen - II. Europa. 4 Bände +1 General-Index.

TERZI M., MARVULli M., 2006 - Priority Zones for Mediterranean protected agro sylvo pastoral landscapes. Ecol. Medit. 32: 29-38. 